\title{
A PÉCSI VILÁGÖRÖKSÉGI HELYSZÍNEK FEJLESZTÉSE
}

\section{THE DEVELOPMENT OF UNESCO WORLD HERITAGE AREA IN PÉCS}

\author{
Németh-Szigeti Renáta ${ }^{1}$, Kósa Balázs ${ }^{2}$, Paczolai Kinga Éva ${ }^{3}$ \\ Pécsi Tudományegyetem, Müszaki és Informatikai Kar, Mérnöki Ismeretek Tanszék, \\ 7624, Magyarország, Pécs, Boszorkány út 2.; Tel./Fax: +36-72-503-650-23836 \\ ${ }^{1}$ reni.szigeti@gmail.com \\ ${ }^{2}$ kosa.balazs@mik.pte.hu \\ 3paczolaik@gmail.com
}

\begin{abstract}
The World Heritage of Pécs is the most valuable historical relic in the city. The conversation, presentation and the continuous development is significant. The parts of the area are the following: the Cella Septichora, the Old Christian Mausoleum and the crypts in the Apáca Street. Through the design process our primal task is the restauration and expansion of the former development in 2006. The study focuses on creating the Cella Septichora concept.
\end{abstract}

Keywords: crypt, early christian, Pécs, World Heritage, UNESCO, Cella Septichora.

\section{Összefoglalás}

A Pécsi Világörökségi Negyed a város legértékesebb történelmi emléke. Megőrzése, bemutatása és folyamatos fejlesztése kiemelt jelentőséggel bír. A terület részei közé tartozik a Cella Septichora, az Ókeresztény Mauzóleum és az Apáca utcai síremlékek. A tervezés során nagyrészt a 2006-os átépítések javítása és bővítése volt a fö feladatunk. A tanulmány a Cella Septichora koncepció alkotására irányul.

Kulcsszavak: sírkamra, ókeresztény, Pécs, Világörökség, UNESCO, Cella Septichora.

\section{A pécsi ókeresztény sírkamrák}

A régészeti bemutatóhely Pécs északnyugati részén található. Nagyjából a XVIII. század elejére datálható az első sírkamra felfedezése. Ezt követően 1782-ben bukkantak rá a Péter Pál sírkamrára, mely a mai napig fontos, értékes és megtekinthető eleme a látogatóközpontnak. A területet 2000-ben helyezte az UNESCO a világörökségi listára. Azóta mind gazdasági, mind eszmei értéke kifogásolhatatlan. $[1][4][5]$

\subsection{Cella Septichora története}

2006-ban Prof. Dr. Bachman Zoltán építész vezetésével megtörténtek a legjelentősebb feltárások, melyekkel látogathatóvá váltak az addig a föld alatt rejtőző emlékeink.[1] A Cella Septichora Látogatóközpont megszületésekor, ahol lehetett, ott a mai járószintbe helyezett üvegfelülettel engedték be a fényt a kápolnatöredékek közé, hogy segítsék megérteni a nézőnek, hogy nem katakombák között, hanem az egykori járószinten sétál. A bejárati tömegről, mely 
a Sétatérre nyílik nagy üvegfelület vonala vezet le a bejárat mellé. A felületen lefolyó víz keresztény szimbólumként jelenik meg a homlokzaton és a födémen egyarányt. A beömlő folyosó a hét karéjos térbe, magába a Cella Septichorába torkollik, amelyet mint egy 300 m2-es üvegfödém fed. A bevilágítón található rácsos útvonal a püspök ünnepélyes bevonulását hívatja szolgálni, valamint az éjjel megvilágításra kerülő kereszt vonal, szintén a keresztény szimbólumra utal.[2] A Cella Septichora Látogatóközpont megnyitása óta, hatalmas jelentőséggel bír a város életében, mely méltón viseli a Világörökségi Terület jelzőt. Megérdemli a felújítási és restaurálási munkálatokat és azt, hogy szeressék és foglalkozzanak vele. A későbbiekben kifejtett koncepcióterv ezt hivatott véghezvinni.

\section{Különleges Kioszk}

A több mint száz éves épület a Sétatér közkedvelt szórakozóhelye. A mai ember nem is gondolná, hogy milyen hányatott sorsa volt. Mivel 1895-ben Piacsek Gyula kioszk terve az elöirányzott költséget túllépte és méreteiben is túlzottnak bizonyult, így végül, a megépült épület terveit Rauch János és Kaufer Sándor készítette el. A Millenniumra készült terv megépülése 1896 nyaráig váratott magára és a sajtó nem fogadta lelkesen. A bírálatban talán a vesztes Piacsek Gyula tábora is részt vehetett, hiszen a tervező által készített magasabb költségvetésü reneszánsz alkotás közelebb állt a fővárosi mintaképhez: az Erzsébet téri kioszk építményéhez. A nehezen létrejött kioszk élete nem volt szerencsés.

Mégis a tervezés során úgy gondoltuk, hogy megtartása és megvédése mindenki számára hasznos és kedvelt megoldás lehetne. Elhelyezkedése szempontjából igen központi helyen szerepel a látogatóközpont életében. Már a 2006-os évi fejlesztések is tárgyalták a kioszkon keresztüli bejárat kialakítását. Jelen tervezés szerint szintén

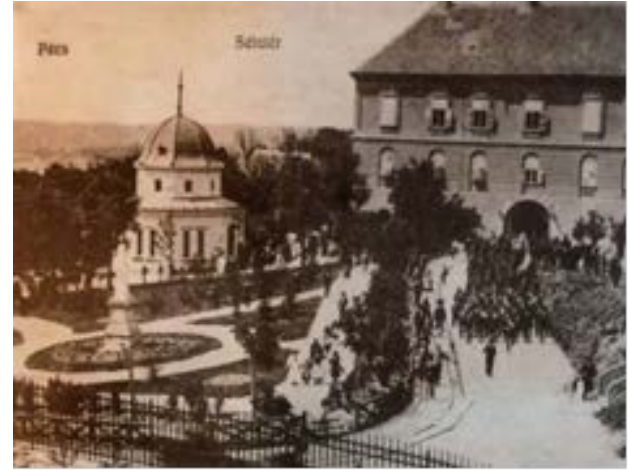

1. ábra. Pécs, Sétatér a kioszkkal a századforduló idején készült képeslapon ${ }^{[3]}$

felmerült a bejárati szituáció kérdése, melyet a későbbiekben bővebben kifejtünk a tanulmányban. [3]

\section{A koncepció megalkotása}

A tervezés során több megrendelői igénynek is eleget kellett tennünk. Nincs megfelelő vizesblokkrendszer, mely egyszerre kiszolgálná az itt dolgozó személyzetet és a látogatókat is. A meglévő jegypénztárhoz kevés tér csatlakozik, így nincs elég hely az eszközöknek, ruhatárnak, és a múzeum shopnak. A központban a Cella Septichora romján belül kialakult téren kívül nincs bemutató terem, melyben előadásokat, oktatást, vagy kiállításokat lehetne rendezni. A kora tavasztól késő őszig tartó helyi idegenforgalmi szezon során számos turista érkezik a városba. A Világörökségi Helyszínek megtekintése szerves részét képezi minden látogatói és városnéző programnak. A fejlesztések egyik fó célja is a látogatók számának növelése és a létesítmény célzott fejlesztése. A jelen bejárati szituáció közvetlen a sétatérre nyílik egy erős „cső” hatású gesztussal, mely kiválóan alkalmas a hangulati átvezetésre a belső térben. Nem biztosít lehetőséget azonban megfelelő előtérképzésre sem a belső sem a külső térben, amire viszont nagy szükség lenne, tekintve, hogy a látogatók jelentős 
része turistacsoporttal érkezik, és így gyakori, hogy két busznyi (50-100) ember egyszerre csoportosul a bejárat előtt, jelentősen korlátozva így a sétány közlekedését és kényelmetlen szituációt teremtve a vendégek számára is. Így keletkezett egyértelmű igény a bejárati szituáció átalakítására és a felmerült igények kielégítésére, miközben ügyelni kellett a meglévő hangulati értékek megtartására.

A tervezett koncepció részeként bővült a meglévő fogadóépület két oktatási térrel a Cella Septichorától déli irányban, valamint a meglévő, megmaradó kioszk épülete alatt. Látogathatóvá tettünk két újonnan feltárt sírkamrát a keleti oldalon (a VIII-as és IXes sírkamrák), melyek ez által körüljárhatóvá váltak és a meglévőséghez igazodva szintén üvegfödém zárást kaptak. A két sírkamra feltárása és bemutatása nehézséget jelentett a tervezés során, mivel a különböző adatforrások eltérő lokalizációt adtak meg. Egyik dokumentum sem tudta pontosan megadni a két sírkamra pozícióját. Emiatt a beruházás során biztosan szükséges lesz a leletek feltárása során és után a tervek adaptálása a valós, akkor már ismert helyzethez. Ez azonban kiszámíthatatlan tényezőt eredményez a kivitelezésben.

A bejárati szituációt az alapján alakítottuk ki, hogy teresedést hozzunk létre már a kültérben, ezáltal elősegítve a megérkezéshez szükséges várakozó helyet. A bejárat helyzetének kiválasztásánál a fó szempont a világosból a sötéten át, ismét a világosba érkezés volt. Ezért alakult ki a kioszktól keletre található folyosó tere. A kioszk beépítése kezdetektől fogva nem volt megoldható, hiszen a magántulajdonban lévő épülethez a tervezés során nem nyúlhatunk.

A homlokzaton kialakult üvegfelület a megérkezés és a múzeum shop bevilágosítását szolgálja ki. A jelenlegi kialakításban ez nem megoldott, hiszen a folyosó végén található információs pult sem helyileg sem pedig méretében nem elégíti ki az igényeket.

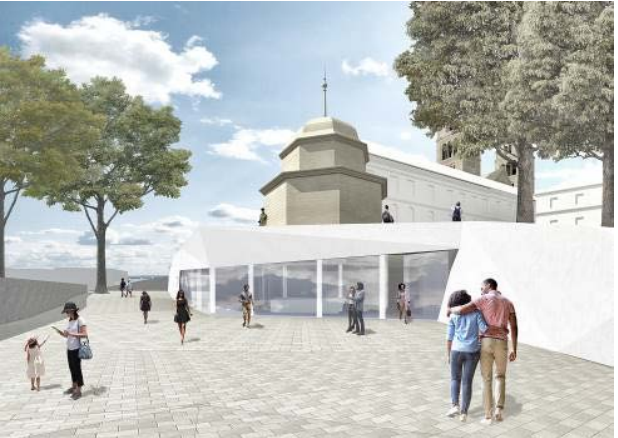

2. ábra. Pécs, Cella Septichora Látogatóközpont koncepció - látványterv

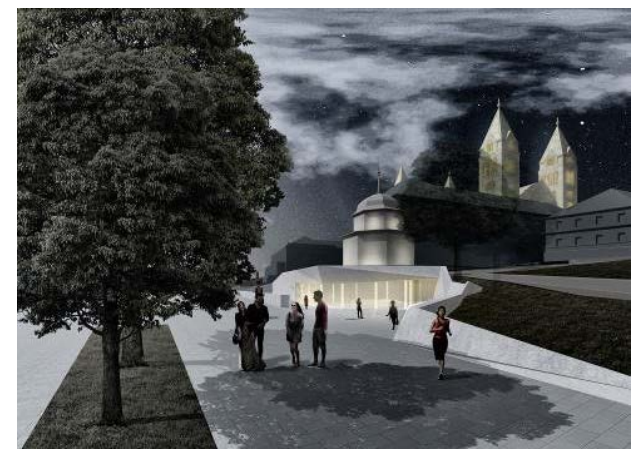

3. ábra. Pécs, Cella Septichora Látogatóközpont koncepció -látványterv

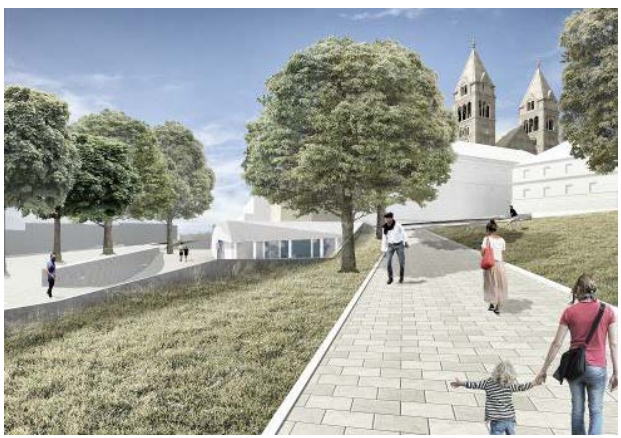

4. ábra. Pécs, Cella Septichora Látogatóközpont koncepció - látványterv

\section{Következtetések}

Ez egy nagyon komplex tervezési feladat, mely kiválóan alkalmas arra, hogy bemutassuk a mai müemlékvédelem és a ter- 
vezés során kialakult gondolatok és a modern felfogás közötti kapcsolatokat.

Leegyszerüsítené és felgyorsítaná a tervezés menetét, ha a meglévő, feltárt sírkamrákról és védőépületekről egy összefogó képet alkotó terv, illetve modell állna a rendelkezésünkre. Megnehezítette a munkát az adatszolgáltatás mennyisége, valamint a minősége és pontossága is. Ezt szeretnénk a későbbiekben elkészülő (építési engedélyezési-, tender-, kivitelezési-) tervekben konkretizálni és egy összefoglaló, úgy nevezett BIM modell segítségével biztosítani, mind a megrendelö, mind a későbbi tervezők és az üzemeltető felé. Egyúttal a műemlékvédelmi leltár digitális állománya is fejlődne.

Célunk, hogy a kialakult koncepció tökéletesen illeszkedjen a város életébe, valamint kielégítse az eredeti épület elkészülte óta felmerült további igényeket.

A Világörökségi Területek megfelelöbb kezelhetőségét továbbá az segítené elő, ha a már kialakuló településképi kézikönyv és rendelet kitérne külön-külön az épített örökséget védő épületekre és azok saját zónát és előírásokat kapnának.

\section{Szakirodalmi hivatkozások}

[1] Szigeti Renáta: A pécsi világörökségi negyed rehabilitációja és a BIM kapcsolata, In: szerk. Koncz István; Szova Ilona: PEME XIV. PhD. - Konferencia, Kiadja a Professzorok az Európai Magyarországért Egyesület, Budapest, 2017, 146-151, ISBN: 978-615-5709-01-2

[2] A Janus Pannonius Múzeum Évkönyve. 43(1998) Janus Pannonius Múzeum, Pécs, 1999, 301-317. Mendöl Zsuzsanna: A sétatéri kioszk. Kaufer Sándor építész (1863-1900) müködése Pécs város mérnöki hivatalában.

[3] Bachman Zoltán: BACHMAN ZOLTÁN. VINCE kiadó, Pécs, 2010, 107-145. ISBN: 978-963-303-001-1

[4] Pozsárkó Csaba; Tóth Zsolt: Pécs a római korban Vezetö a pécsi világörökség helyszíneihez. Kiadja a Zsolnay Örökségkezelő Nonprofit Kft., Pécs, 2011, 6-9. ISBN: 978963-89319-0-0

[5] Bozóky Anita: Világörökségi helyszínek Pécs. Múltunk tükre, jövőnk gyökere. Kiadja a Zsolnay Örökségkezelő Nonprofit Kft., Pécs, 2013,1-23. ISBN: 978-963-89844-3-2. 